\title{
Evaluation of the bacterial diversity in the feces of cattle using I6S rDNA bacterial tag-encoded FLX amplicon pyrosequencing
} (bTEFAP)

\author{
Scot E Dowd*1,3,4, Todd R Callaway2, Randall D Wolcott ${ }^{3}$, Yan Sun ${ }^{3}$, \\ Trevor McKeehan ${ }^{3}$, Robert G Hagevoort ${ }^{5}$ and Thomas S Edrington ${ }^{2}$
}

\begin{abstract}
Address: ${ }^{1}$ USDA-ARS Livestock Issues Research Unit, Lubbock, TX 79403, USA, ${ }^{2}$ USDA-ARS, Food and Feed Safety Research Unit, College Station, TX 77845, USA, ${ }^{3}$ Medical Biofilm Research Institute, Lubbock, TX 79410, USA, ${ }^{4}$ Research and Testing Laboratory, Lubbock, TX 79410, USA and ${ }^{5}$ New Mexico State University, Clovis, NM 88101, USA

Email: Scot E Dowd* - sdowd@pathogenresearch.org; Todd R Callaway - Todd.Callaway@ARS.USDA.GOV;

Randall D Wolcott - Randy@randallwolcott.com; Yan Sun - s_yan_99@yahoo.com; Trevor McKeehan - trevor.d.mckeehan@ttu.edu;

Robert G Hagevoort - dairydoc@nmsu.edu; Thomas S Edrington -Tom.Edrington@ARS.USDA.GOV

* Corresponding author
\end{abstract}

Published: 24 July 2008

BMC Microbiology 2008, 8:125 doi:10.1 186/147/-2180-8-125

This article is available from: http://www.biomedcentral.com/147I-2180/8/125

(C) 2008 Dowd et al; licensee BioMed Central Ltd.

This is an Open Access article distributed under the terms of the Creative Commons Attribution License (http://creativecommons.org/licenses/by/2.0), which permits unrestricted use, distribution, and reproduction in any medium, provided the original work is properly cited.

\begin{abstract}
Background: The microbiota of an animal's intestinal tract plays important roles in the animal's overall health, productivity and well-being. There is still a scarcity of information on the microbial diversity in the gut of livestock species such as cattle. The primary reason for this lack of data relates to the expense of methods needed to generate such data. Here we have utilized a bacterial tag-encoded FLX 16s rDNA amplicon pyrosequencing (bTEFAP) approach that is able to perform diversity analyses of gastrointestinal populations. bTEFAP is relatively inexpensive in terms of both time and labor due to the implementation of a novel tag priming method and an efficient bioinformatics pipeline. We have evaluated the microbiome from the feces of 20 commercial, lactating dairy cows.
\end{abstract}

Results: Ubiquitous bacteria detected from the cattle feces included Clostridium, Bacteroides, Porpyhyromonas, Ruminococcus, Alistipes, Lachnospiraceae, Prevotella, Lachnospira, Enterococcus, Oscillospira, Cytophage, Anaerotruncus, and Acidaminococcus spp. Foodborne pathogenic bacteria were detected in several of the cattle, a total of 4 cows were found to be positive for Salmonella spp (tentative enterica) and 6 cows were positive for Campylobacter spp. (tentative lanienae).

Conclusion: Using bTEFAP we have examined the microbiota in the feces of cattle. As these methods continue to mature we will better understand the ecology of the major populations of bacteria the lower intestinal tract. This in turn will allow for a better understanding of ways in which the intestinal microbiome contributes to animal health, productivity and wellbeing.

\section{Background}

Research on the microbial diversity of the gastrointestinal of livestock is surprisingly scarce, even though it is well understood that bacteria in the gut are vital components that contribute to an animals' health and well-being. The bacterial populations that reside in the gut of animals are 
diverse and numerous; intestinal populations often exceed $10^{11} \mathrm{CFU} /$ gram feces $[1,2]$. The majority of these bacteria are vital to the maintenance of animal's health and it is expected that even minor perturbations in these populations may cause dramatic shifts that can affect livestock productivity [3-5]. These beneficial health effects relate to the ability of these intestinal bacterial populations to supply vital nutrients, convert metabolites and beneficially interact with host cells [6-8]. Information on microbial diversity within the gastrointestinal tract of humans has increased in recent years as a result of $16 \mathrm{~S}$ rDNA-based analyses $[9,10]$, yet similar data on the microbiomes of livestock is lacking $[11,12]$.

The primary reasons for the lack of knowledge regarding the composition of the intestinal microbiome relates to the difficulty and expense of methods used to evaluate these populations. Traditionally culture-based methods have been used to identify and enumerate commensal members of the ruminal and intestinal flora [13-15]. Culture-based methods are extremely time-consuming and to date we have only been able to culture approximately $1 \%$ of the bacteria in the gut [16]. Thus, culture based methods are extremely biased in their evaluation of microbial diversity, tending to overestimate the importance of bacterial species such as Escherichia coli that easily grow on an agar surface.

Molecular methodologies developed over the past decade now enable researchers to examine the diversity of the gut microflora independent of cultural methods [17]. Although molecular approaches can also introduce their own forms of bias such as the ability to detect both viable and non-viable bacteria [18-20] they currently provide the most powerful tools available for elucidating the diversity of animal microbiomes $[4,11,12,15]$. The use of rapid sequencing technologies combined with molecular methods is becoming a gold standard for evaluating the microbiomes of animals [21-25]. In the present study we utilized a novel tag bacterial diversity amplification method that uses massively parallel pyrosequencing techniques to determine the diversity within the intestinal microbiota.

\section{Results and Discussion}

Recent research related to host physiology (obesity) and the gastrointestinal bacterial populations have sparked a renewed interest in understanding the gut microbiome $[26,27]$. Further studies have indicated that, in humans, intestinal microbial populations of clostridia could be responsible for the development of autism $[28,29]$. These studies gained much attention because they have correlated physiological conditions with specific microbial populations in the gut. Such studies have raised a pertinent question: is there a microbiome profile in food ani- mals that can increase production efficiency, product quality, and/or food safety? This question has been obliquely addressed through the use of probiotics, prebiotics and competitive exclusion products which seek to establish a healthy "normal" gastrointestinal flora in animals that can improve animal performance or prevent colonization of the animal with pathogens, including zoonotic pathogens $[3,30,31]$.

In our present study, the bTEFAP analysis of fecal samples from 20 individual dairy cows displayed a high diversity of bacterial species and genera. Among these cows there were 274 different bacterial species detected corresponding to 142 separate genera. As several thousand sequences per sample were analyzed (minimum 1732, maximum 3224) we were able to detect populations below $0.1 \%$, giving a relatively deep and thorough examination of the predominant bacterial populations in these fecal samples.

It has been indicated that the microbial population of lower intestinal bacteria of cattle are dominated by strict anaerobes such as Bacteroides spp., Clostridium spp., and Bifidobacterium spp while facultative anaerobes, such as the enterobacteriaceae (e.g. E. coli), are typically reported to occur in numbers at least 100-fold lower than the strict anaerobes [32]. This supports findings from the current study in which the predominant genera found in each of the samples were Clostridium, Bacteroides, Porphyromonas, Ruminococcus, Alistipes, Lachnospiraceae, Prevotella, Lachnospira, Bacteroidales, Akkermansia, and Enterococcus spp (Table 1). We can see that each of the dairy fecal samples was surprisingly consistent in that Clostridium, Porphyromonas, Bacteroides, Ruminococcus, Alistipes, Lachnospira, and Prevotella spp were highly prevalent and found in all of the cattle samples.

Clostridium spp. is a broad genus and has been described as a "trash can" genus (Steve Zinder, Cornell University, Personal communication), and are ubiquitous in the gastrointestinal tract. Clostridia can both positively and negatively influence the host animal. These effects are typically specifically associated with the individual Clostridium species involved $[33,34]$. Many have negative influences on animal health including species such as $C$. perfringens, C. tetani, C. botulinum, and C. difficile [35-37] and can also cause significant productivity problems including reducing the protein availability in fresh forage diets [38]. Conversely, some Clostridium spp. may also be beneficial and improve digestion of complex organic matter such as cellulose and even act as beneficial probiotics [39-43]. In the present study, we detected total of 37 separate species of Clostridium spp. (tentatively straminisolvens, hathewayi, leptum, fimetarium, orbiscindens, lactatifermentans were the most prevalent) and Clostridium spp. was the most common and diverse genus identified. 
Table I: Most ubiquitous genera identified from the cow fecal samples ( $n=20$ cows).

\begin{tabular}{|c|c|c|c|c|}
\hline ID & $\begin{array}{r}\text { Number of sequences of } \\
\text { each genus }\end{array}$ & $\begin{array}{r}\text { Number of cow samples } \\
\text { containing each genus }\end{array}$ & $\begin{array}{l}\text { Average \% of population } \\
\text { across all cows (std dev) }\end{array}$ & $\begin{array}{l}\text { Range of population from all } \\
\text { cows (\%) }\end{array}$ \\
\hline Clostridium spp & 8701 & 20 & $19.0(3.57)$ & 13.9-25.4 \\
\hline Bacteroides spp & 4326 & 20 & $9.26(2.17)$ & $5.2-13.7$ \\
\hline Porphyromonas spp & 3435 & 20 & $7.34(2.28)$ & $2.08-11.7$ \\
\hline Ruminococcus spp & 3286 & 20 & $3.57(1.5)$ & $0.79-6.96$ \\
\hline Alistipes spp & 3051 & 20 & $6.61(1.35)$ & $3.54-8.71$ \\
\hline Lachnospiraceae-like & 2716 & 20 & $5.7(2.77)$ & $2.31-12.2$ \\
\hline Prevotella spp & 2499 & 20 & $5.47(2.13)$ & $2.31-9.89$ \\
\hline Porphyromonas-like & 2097 & 14 & $6.37(2.02)$ & $0.61-\mid 1.21$ \\
\hline Bacteroidales spp & $|87|$ & 20 & $4.11(2.36)$ & $1.1-9.9$ \\
\hline Lachnospira spp & 1753 & 20 & $3.73(2.18)$ & $0.5-7.1$ \\
\hline Akkermansia spp & 1464 & 19 & $3.42(1.97)$ & $0.56-8.64$ \\
\hline Enterococcus spp & 1335 & 20 & $2.95(1.91)$ & $0.73-7.89$ \\
\hline Firmicutes spp & 883 & 20 & $1.88(0.88)$ & $0.36-3.9$ \\
\hline Oscillospira spp & 751 & 20 & $1.59(0.62)$ & $0.2-2.48$ \\
\hline Prevotellaceae-like & 747 & 13 & $2.6(3.19)$ & $0.1-11.03$ \\
\hline Cytophaga spp & 638 & 20 & $1.35(0.76)$ & $0.15-2.95$ \\
\hline Eubacterium spp & 598 & 19 & $1.31(0.53)$ & $0.47-2.74$ \\
\hline Francisella spp & 575 & 15 & $1.65(0.75)$ & $0.16-1.65$ \\
\hline Clostridiales spp & 534 & 20 & $1.15(0.58)$ & $0.47-2.51$ \\
\hline Papillibacter spP & 498 & 18 & $\mathrm{I} .13(0.75)$ & $0.26-2.41$ \\
\hline Spiroplasma spp & 490 & 19 & $1.13(0.52)$ & $0.39-2.37$ \\
\hline Sedimentibacter spp & 411 & 18 & $1.04(0.77)$ & $0.39-3.74$ \\
\hline Treponema spp & 409 & 19 & $0.93(0.54)$ & $0.12-1.7$ \\
\hline Victivallis SpP & 371 & 13 & $1.14(0.86)$ & $0.27-3.19$ \\
\hline Peptococcus spp & 310 & 19 & $0.71(0.49)$ & $0.16-1.94$ \\
\hline Escherichia spp & 254 & 17 & $0.68(0.75)$ & $0.11-3.11$ \\
\hline Anaerotruncus spp & 245 & 20 & $0.54(0.24)$ & $0.19-1.01$ \\
\hline Anaerophaga spp & 216 & 10 & $0.9(0.44)$ & $0.41-1.83$ \\
\hline Acidaminococcus spp & 206 & 20 & $0.46(0.23)$ & $0.15-1.16$ \\
\hline Paenibacillus spp & 194 & 13 & $0.59(0.29)$ & $0.13-1.15$ \\
\hline Streptococcus spp & 193 & 15 & $0.55(0.31)$ & $0.17-1.16$ \\
\hline Fucophilus spp & 191 & 15 & $0.53(0.26)$ & $0.17-1.03$ \\
\hline Flavobacteriaceae spp & 191 & 11 & $0.81(0.94)$ & $0.19-3.43$ \\
\hline Alterococcus spp & 190 & 10 & $0.78(0.39)$ & $0.26-1.53$ \\
\hline Chryseobacterium spp & 187 & 15 & $0.53(0.29)$ & $0.13-1.02$ \\
\hline Catabacter spp & 169 & 11 & $0.64(0.42)$ & $0.16-1.29$ \\
\hline Unknown-clusterC & 168 & 13 & $0.56(0.4 I)$ & $0.13-1.33$ \\
\hline Peptostreptococcus spp & 149 & 15 & $0.44(0.30)$ & $0.1-1.17$ \\
\hline Roseburia spp & 146 & 11 & $0.59(0.41)$ & $0.14-1.59$ \\
\hline Sporobacter spp & $|4|$ & 15 & $0.41(0.29)$ & $0.11-1.31$ \\
\hline Clostridiaceae-like & 117 & 11 & $0.45(0.24)$ & $0.16-0.87$ \\
\hline Acholeplasma spp & 94 & 11 & $0.37(0.25)$ & $0.12-0.88$ \\
\hline Unknown-clusterP & 65 & 10 & $0.29(0.15)$ & $0.12-0.55$ \\
\hline
\end{tabular}

Complete data is provided in supplemental data files. The ID is the genera identified ordered by most abundant sequences. The number of cows that were positive for each genus, the average percentage of the total bacterial population across all cows, and the range of the total population represented by each genus across all cows sampled is also shown in the table.

Clostridium spp. accounted for approximately $20 \%$ of the total microbial populations and were detected in all of the cattle in this study.

Bacteroides spp. were also identified in all 20 cattle (and tentatively represented the species stercoris, denticanum, vulgates, caccae, cillulosolvens). Bacteroides are well-known intestinal bacteria that can be both beneficial and harmful [44]. Bacteroides are also noted to participate in natural genetic transfer of antimicrobial resistance genes [45]. Another genus that was highly prevalent in the feces of these dairy cattle was Porphyromonas spp. There was no clear identification for the most prevalent Porphyromonas species in this study though cangingivalis, and levii were two of the tentative species identified; $P$. levii has been associated with bovine necrotic vulvovaginitis [46] and bovine footrot [47]. Little else is known about the role of this bacteria in the gut though one other study identified 
this bacteria as part of the intestinal community of chickens [48]. Thus it appears that this bovine pathogen may have a reservoir in the feces so that it can be spread to the vulva and feet where it causes disease in cattle.

Alistipes spp (tentative finegoldii) and Prevotella spp. were previously classified as members of the genus Bacteroides $[49,50]$. Other than this original description there are only a handful of reports of Alistipes as a member of the intestinal population, including one study which identified this organism as being isolated from the ceca of turkeys [51]. Prevotella spp (tentative oralis, ruminicola and albensis) is a well known genus associated with the rumen of cattle [49,52-54] and is associated with ruminal carbohydrate and protein fermentation. Lachnospira spp. (tentative pectinoschiza) is another genus which has been poorly characterized in environments other than the rumen and has only been occasionally detected in the feces of pigs and humans $[55,56]$. This however may be one of the first studies to show these genera as a predominant population in the lower intestinal tract of cattle.

Generic E. coli are easily cultured and ubiquitous in the feces of animals so that they are often used as a marker of fecal contamination in water supplies, however they typically comprise less than $1 \%$ of the intestinal bacterial populations [32]. The colony forming unit counts of $E$ coli in feces are typically in the $10^{4}$ to $10^{6}$ range while total microbial counts are in the $10^{10}$ to $10^{11}$ bacteria per gram of feces range[32]. Because of this it is not surprising that E. coli were not detected in feces from three of the cows. These results are reflective of the culture-based bias inherent to studies enumerating the easily grown $E$. coli in vitro while major populations such as Clostridium and Bacteroides spp. are fastidious and typically require specialized anaerobic growth conditions.

Zoonotic pathogenic bacteria, such as Salmonella enterica and E. coli O157:H7 can live in the lower gut of cattle and cause human illnesses through carcass contamination, farm run-off, or crop contamination [57-60]. Many live animal anti-pathogen interventions that are currently marketed or have been proposed share a mode of action that alters the microbial ecology of the gut to exclude or to push out these pathogens $[61,62]$. However, in order to effectively utilize beneficial microbial populations against foodborne pathogens we must understand the normal ecology of the gastrointestinal tract. There are an estimated 1.4 million illnesses and over 500 deaths attributed to salmonellosis in the United States annually [63]. Salmonella enterica is a common inhabitant of the gastrointestinal tracts of cattle. Consequently beef and dairy products are also well known sources of human Salmonellosis [59,64-66]. In the present study using bTEFAP, we detected Salmonella spp. in 4 of the cattle fecal samples.
Similarly, Campylobacter is another major cause of foodborne illness [63] and was detected in 6 of the cow samples (Additional file 1). The zoonotic pathogen E. coli serotype O157:H7 is commonly associated with the intestinal mucosa of cattle [67]. Although the bTEFAP analysis method has been shown to have the ability to differentiate this serotype within E. coli (data not shown) they were not detected or differentiated in this study. From the perspective of rapid pathogen detection, one of the most interesting observations from this study was the ability of bTEFAP to detect Salmonella spp and Campylobacter spp (Supplemental data). This finding illustrates the potential use of the bTEFAP technology as a universal bacterial diagnostic and screening tool for bacterial pathogens and indicates the potential power of bTEFAP as a screening tool in epidemiological studies in animals and humans.

Most of the existing studies seeking to evaluate microbial diversity in the intestinal tract utilize fingerprinting methodologies such as denaturing gradient gel electrophoresis (DGGE) [68]. Fingerprinting methods typically ignore identities of the microbial populations in favor of a simple but important measure of diversity. Culture-based methods that have been used in other diversity estimates and of course over-represent the genera that can be grown easily in vitro $[69,70]$. A number of studies [11] have also evaluated powerful yet classical sequencing approaches, which involve PCR amplification, cloning and Sanger sequencing. Even accounting for potential bias of molecular methods, it is apparent that such methods are the most powerful tools currently available for evaluating the intestinal microbial population of animals. Widespread use of molecular methodologies may usher in a new age in which such diversity studies are no longer limited to a handful of laboratories with abundance of funding and labor.

\section{Conclusion}

In the field of animal nutrition, the microbial processes within the rumen and intestinal tract of food animals remain largely a "black box". Investigators such as Robert Hungate and Marvin Bryant characterized some ruminal and intestinal microbial populations, and related the biochemistry of these microorganisms to their roles in animal nutrition $[1,71]$; however they were limited to the use of culture-based methodologies. The new method of bTEFAP is not limited to detecting organisms via culture methods, and can be used to define what constitutes a "healthy" or an "unhealthy" microbiome profile by correlating populations of bacterial species with dietary energy and protein utilization, host growth rate and efficiency, host gene expression, and host immune function [72-75]. Recent research aimed at humans has underscored the role that intestinal microbial populations plays in human health and physiology. Thus fully understanding the 
diversity of the gut community in animals, and how these populations and communities relate to animal performance and displacement of zoonotic pathogen infections in livestock is crucial to making improvements in animal health, productivity and food safety. As this bTEFAP method matures we should have a vastly improved ability to evaluate and monitor changes in microbiomes such as those in the gastrointestinal tract of livestock.

\section{Methods \\ Cattle samples}

Fecal grab samples were collected from adult, lactating Holstein dairy cattle $(n=20)$ on a large $(>3,000$ head herd) in the Southwestern United States. Cattle were fed a typical Total Mixed Ration (TMR) commonly fed to dairy cattle in the southwestern U.S. The ration was comprised of chopped alfalfa hay (approximately 20\% DM of total ration) and a mixture of cracked corn, soybean meal, cottonseed meal and trace mineral salts. The cows ranged from 18 to $217 \mathrm{~d}$ of lactation. Cows were visibly healthy and no illnesses amongst these cows were reported subsequent to the collection. Samples (30-50 g each) were each collected from freshly voided pats off the pen floor. Fecal samples were stored on wet ice and shipped overnight to the laboratory for analysis.

\section{DNA extraction}

Total genomic DNA was extracted from fecal samples using a QIAamp stool DNA mini kit and its manufacturers recommended methods (Qiagen, Valencia, CA). DNA samples were quantified using a Nanodrop spectrophotometer (Nyxor Biotech, Paris, France).

\section{bTEFAP Sequencing PCR}

The bTEFAP method was performed by the Research and Testing Laboratory (Lubbock, TX). All DNA samples were adjusted to $100 \mathrm{ng} / \mu \mathrm{l}$. A $100 \mathrm{ng}(1 \mu \mathrm{l})$ aliquot of each samples DNA was used for a $50 \mu \mathrm{l}$ PCR reaction. The $16 \mathrm{~S}$ universal Eubacterial primers 530F (5'-GTG CCA GCM GCN GCG G) and 1100R (5'-GGG TTN CGN TCG TTG) were used for amplifying the $600 \mathrm{bp}$ region of 16S rRNA genes. HotStarTaq Plus Master Mix Kit (Qiagen, Valencia, CA) was used for PCR under the following conditions: $94^{\circ} \mathrm{C}$ for 3 minutes followed by 32 cycles of $94^{\circ} \mathrm{C}$ for 30 seconds; $60^{\circ} \mathrm{C}$ for 40 seconds and $72^{\circ} \mathrm{C}$ for 1 minute; and a final elongation step at $72^{\circ} \mathrm{C}$ for 5 minutes. A secondary PCR was performed for FLX (Roche, Nutley, New Jersey) amplicon sequencing under the same condition by using designed special fusion primers with different tag sequences as: LinkerA-Tags-530F and LinkerB-1100R (Table 2). The use of a secondary PCR prevents amplification any potential bias that might be caused by inclusion of tag and linkers during initial template amplification reactions. After secondary PCR all amplicon products from different samples were mixed in equal volumes, and purified using Agencourt Ampure beads (Agencourt Bioscience Corporation, MA, USA). As a note: mixing of the reactions based upon amplicon concentrations rather than volume is preferred.

Table 2: Primer sequences utilized for pig samples during bTEFAP

\begin{tabular}{ll}
\hline Name & Primer sequence (5'-3') \\
\hline $454-F 30$ & GCCTCCCTCGCGCCATCAGCGCACTACGTGTGCCAGCMGCNGCGG \\
$454-F 31$ & GCCTCCCTCGCGCCATCAGCGCAGCTGTTGTGCCAGCMGCNGCGG \\
$454-F 32$ & GCCTCCCTCGCGCCATCAGCGCATACAGTGTGCCAGCMGCNGCGG \\
$454-F 33$ & GCCTCCCTCGCGCCATCAGCGCATCTATAGTGCCAGCMGCNGCGG \\
$454-F 34$ & GCCTCCCTCGCGCCATCAGCGCATTGGTGGTGCCAGCMGCNGCGG \\
$454-F 35$ & GCCTCCCTCGCGCCATCAGCGCCAGAAAAGTGCCAGCMGCNGCGG \\
$454-F 36$ & GCCTCCCTCGCGCCATCAGTGTGACGTACGTGCCAGCMGCNGCG \\
$454-F 37$ & GCCTCCCTCGCGCCATCAGTGTGTGCATAGTGCCAGCMGCNGCGG \\
$454-F 38$ & GCCTCCCTCGCGCCATCAGTGTGTCCTCAGTGCCAGCMGCNGCGG \\
$454-F 39$ & GCCTCCCTCGCGCCATCAGTGTGCATCACGTGCCAGCMGCNGCGG \\
$454-F 40$ & GCCTCCCTCGCGCCATCAGTGTGCCTAGAGTGCCAGCMGCNGCGG \\
$454-F 41$ & GCCTCCCTCGCGCCATCAGTGTACATAGTGTGCCAGCMGCNGCGG \\
$454-F 42$ & GCCTCCCTCGCGCCATCAGTGTACATTGAGTGCCAGCMGCNGCGG \\
$454-F 43$ & GCCTCCCTCGCGCCATCAGTGTACATTGTGTGCCAGCMGCNGCGG \\
$454-F 44$ & GCCTCCCTCGCGCCATCAGTGTACCAACAGTGCCAGCMGCNGCGG \\
$454-F 45$ & GCCTCCCTCGCGCCATCAGTGTACCAACTGTGCCAGCMGCNGCGG \\
$454-F 46$ & GCCTCCCTCGCGCCATCAGTGTACCAATCGTGCCAGCMGCNGCGG \\
$454-F 47$ & GCCTCCCTCGCGCCATCAGTGTACCAGATGTGCCAGCMGCNGCGG \\
$454-F 48$ & GCCTCCCTCGCGCCATCAGTGTACCCATAGTGCCAGCMGCNGCGG \\
$454-F 49$ & GCCTCCCTCGCGCCATCAGTGTACAGGGTGTGCCAGCMGCNGCGG \\
$454-F 50$ & GCCTCCCTCGCGCCATCAGTGTACCTATCGTGCCAGCMGCNGCGG \\
linkerB-II00R & GCCTTGCCAGCCCGCTCAGGGGTTNCGNTCGTTG \\
&
\end{tabular}




\section{bTEFAP FLX massively parallel pyrosequencing}

In preparation for FLX sequencing (Roche, Nutley, New Jersey), the DNA fragments size and concentration were accurately measured by using DNA chips under a Bio-Rad Experion Automated Electrophoresis Station (Bio-Rad Laboratories, CA, USA) and a TBS-380 Fluorometer (Turner Biosystems, CA, USA). A 9.6 E+06 sample of double-stranded DNA molecules/ $\mu$ l with an average size of 625 bp were combined with 9.6 million DNA capture beads, and then amplified by emulsion PCR. After bead recovery and bead enrichment, the bead-attached DNAs were denatured with $\mathrm{NaOH}$, and sequencing primers were annealed. A two-region 454 sequencing run was performed on a $70 \times 75$ GS PicoTiterPlate (PTP) by using a Genome Sequencer FLX System (Roche, Nutley, New Jersey). It should be noted that 100 total samples were run within this same FLX 2-region sequencing reaction. The additional 79 tagged samples were associated with unrelated studies. All FLX related procedures were performed following Genome Sequencer FLX System manufacturers instructions (Roche, Nutley, New Jersey).

\section{bTEFAP Tag design}

A custom script written in $\mathrm{C \#}$ was utilized to generate all possible combinations of 10-mer oligonucleotide tags with GC \% between 40 and 60\%. From this pool we then chose 20 individual tags (Table 2).

\section{bTEFAP Sequence processing pipeline}

Custom software written in C\# within a Microsoft ${ }^{\circledR}$.NET (Microsoft Corp, Seattle, WA) development environment was utilized for all post sequencing processing. Discussion of software code is outside the scope of this report however a description of the algorithm follows. Quality trimmed sequences obtained from the FLX sequencing run were processed using a custom scripted bioinformatics pipeline. In short, quality trimmed sequencing reads were derived directly from FLX sequencing run output files. Tags were extracted from the multi-FASTA file into individual sample specific files based upon the tag sequence. Tags which did not have $100 \%$ homology to the sample designation were not considered. Sequences which were less than 150 bp after quality trimming were not considered. The total number of sequences among the 20 samples was 49635. These sequences were fairly divided among the 20 samples averaging close to 2500 sequence reads per sample. The resultant individual sample after parsing the tags into individual FASTA files were assembled using CAP3 [76]. The ace files generated by CAP3 were then processed to generate a secondary FASTA file containing the tentative consensus (TC) sequences of the assembly along with the number of reads integrated into each consensus. TC were required to have at least 3fold coverage. The resulting TC FASTA for each sample was then evaluated using BLASTn [77] against a custom database derived from the RDP-II database [78] and GenBank http://ncbi.nlm.nih.gov. The sequences contained within the curated 16 S database were both $>1200$ bp and considered of high quality based upon RDP-II standards. A post processing algorithm generated best-hit files with E-values $<10$ e- 114 and bit scores $>400$. The identities of all hits were greater than $98 \%$. These parameters, based upon an average TC length of 260 bp have been previously evaluated to enable reliable identification at the genus and species level (data not shown). However, identification at the species level will only be considered putative for the purpose of this pilot study. Following best-hit processing a secondary post-processing algorithm was utilized to combine genus designations generating a list of genera IDs and their relative predicted abundance within the given sample.

\section{Statistics}

Statistics were performed using the Basic comparative functions of JMP 6.0 (SAS institute, Cary, NC).

\section{Authors' contributions}

SED helped conceived of the project, developed the methods and software, wrote first drafts of the manuscript, TRC helped conceive of the project, drafting of the manuscript, performed sample collection, RDW assisted with the development of methods, YS performed bTEFAP laboratory studies, TM was responsible for software programming, RGH managed animal aspects of the project, TSE helped with animal studies and manuscript drafts.

\section{Additional material}

\section{Additional File 1}

Table providing all of the genus identified in this cattle fecal microbiome pilot study. The data is sorted by the number of fecal samples in which each genera was detected and then by the total number of sequences corresponding to this genera.

Click here for file

[http://www.biomedcentral.com/content/supplementary/14712180-8-125-S1.doc]

\section{Acknowledgements}

Mention of trade names or commercial products in this manuscript is solely for the purpose of providing specific information and does not imply recommendation or endorsement by the U.S. Department of Agriculture. Thanks to Chunfa Wu and Ethan Smith for help with DNA extractions.

\section{References}

I. Hungate RE: The Rumen and its microbes New York, NY, Academic Press; 1966

2. Yokoyama MG, Johnson KA: Microbiology of the rumen and intestine. In The Ruminant Animal: Digestive Physiology and Nutrition Edited by: Church DC. Englewood Cliffs, N.J., Waveland Press; 1988: $125-144$. 
3. Dunkley KD, Dunkley CS, Njongmeta NL, Callaway TR, Hume ME Kubena LF, Nisbet DJ, Ricke SC: Comparison of in vitro fermentation and molecular microbial profiles of high-fiber feed substrates incubated with chicken cecal inocula. Poult Sci 2007, 86:80I-8I0

4. Callaway TR, Edrington TS, Anderson RC, Byrd JA, Nisbet DJ: Gastrointestinal microbial ecology and the safety of our food supply as related to Salmonella. J Anim Sci 2007.

5. Canibe N, Hojberg O, Hojsgaard S, Jensen BB: Feed physical form and formic acid addition to the feed affect the gastrointestinal ecology and growth performance of growing pigs. J Anim Sci 2005, 83: I287-1302.

6. Flint HJ, Duncan SH, Scott KP, Louis P: Interactions and competition within the microbial community of the human colon: links between diet and health. Environ Microbiol 2007, 9:|I0I-IIII.

7. Flint HJ: Polysaccharide breakdown by anaerobic microorganisms inhabiting the Mammalian gut. Adv Appl Microbiol 2004 , 56:89-120

8. Walker AW, Duncan SH, William Leitch EC, Child MW, Flint HJ: pH and peptide supply can radically alter bacterial populations and short-chain fatty acid ratios within microbial communities from the human colon. Appl Environ Microbiol 2005 , 7 I:3692-3700.

9. Eckburg PB, Bik EM, Bernstein CN, Purdom E, Dethlefsen L, Sargent M, Gill SR, Nelson KE, Relman DA: Diversity of the human intestinal microbial flora. Science 2005, 308:1635-1638.

10. Ley RE, Peterson DA, Gordon JI: Ecological and evolutionary forces shaping microbial diversity in the human intestine. Cell 2006, I 24:837-848.

II. Pryde SE, Richardson AJ, Stewart CS, Flint HJ: Molecular analysis of the microbial diversity present in the colonic wall, colonic lumen, and cecal lumen of a pig. Appl Environ Microbiol 1999 65:5372-5377.

12. Zhu WY, Williams BA, Konstantinov SR, Tamminga S, de Vos WM, Akkermans AD: Analysis of I6S rDNA reveals bacterial shift during in vitro fermentation of fermentable carbohydrate using piglet faeces as inoculum. Anaerobe 2003, 9: I75-180.

13. Flint $\mathrm{H}$ ]: The rumen microbial ecosystem--some recent developments. Trends Microbiol I997, 5:483-488.

14. Jenny BF, Vandijk HJ, Collins JA: Performance and fecal flora of calves fed a Bacillus subtilis concentrate. I Dairy Sci 1991, 74:1968-1973

15. Rada V, Vlkova E, Nevoral J, Trojanova I: Comparison of bacterial flora and enzymatic activity in faeces of infants and calves. FEMS Microbiol Lett 2006, 258:25-28.

16. Nocker A, Burr M, Camper AK: Genotypic microbial community profiling: a critical technical review. Microb Ecol 2007 54:276-289.

17. Dahllof I: Molecular community analysis of microbial diversity. Curr Opin Biotechnol 2002, 13:213-217.

18. Farrelly V, Rainey FA, Stackebrandt E: Effect of genome size and rrn gene copy number on PCR amplification of I6S rRNA genes from a mixture of bacterial species. Appl Environ Microbiol |995, 6 I:2798-280|

19. von WF, Gobel UB, Stackebrandt E: Determination of microbial diversity in environmental samples: pitfalls of PCR-based rRNA analysis. FEMS Microbiol Rev 1997, 2 I:2 I 3-229.

20. Suzuki MT, Giovannoni SJ: Bias caused by template annealing in the amplification of mixtures of I6S rRNA genes by PCR. Appl Environ Microbiol 1996, 62:625-630.

21. Dowd SE, Sun Y, Secor PR, Rhoads DD, Wolcott BM, James GA, Wolcott RD: Survey of bacterial diversity in chronic wounds using Pyrosequencing, DGGE, and full ribosome shotgun sequencing. BMC Microbiol 2008, 8:43.

22. Roesch LF, Fulthorpe RR, Riva A, Casella G, Hadwin AK, Kent AD Daroub SH, Camargo FA, Farmerie WG, Triplett EW: Pyrosequencing enumerates and contrasts soil microbial diversity. ISME J 2007, I:283-290.

23. Huse SM, Huber JA, Morrison HG, Sogin ML, Welch DM: Accuracy and quality of massively parallel DNA pyrosequencing. Genome Biol 2007, 8:R I 43.

24. Cristea-Fernstrom M, Olofsson M, Chryssanthou E, Jonasson Petrini B: Pyrosequencing of a short hypervariable I 6S rDNA fragment for the identification of nontuberculous mycobac- teria--a comparison with conventional I6S rDNA sequencing and phenotyping. APMIS 2007, I I 5: I252-I259.

25. Liu Z, Lozupone C, Hamady M, Bushman FD, Knight R: Short pyrosequencing reads suffice for accurate microbial community analysis. Nucleic Acids Res 2007, 35:e 120.

26. Ley RE, Turnbaugh PJ, Klein S, Gordon Jl: Microbial ecology: human gut microbes associated with obesity. Nature 2006, 444: $1022-1023$

27. Turnbaugh PJ, Ley RE, Mahowald MA, Magrini V, Mardis ER, Gordon II: An obesity-associated gut microbiome with increased capacity for energy harvest. Nature 2006, 444: I027-I03I.

28. Bolte ER: Autism and Clostridium tetani. Med Hypotheses 1998 , 5 I: I33-| 44

29. Finegold SM, Molitoris D, Song Y, Liu C, Vaisanen ML, Bolte E, McTeague M, Sandler R, Wexler H, Marlowe EM, Collins MD, Lawson PA, Summanen P, Baysallar M, Tomzynski TJ, Read E, Johnson E, Rolfe R, Nasir P, Shah H, Haake DA, Manning P, Kaul A: Gastrointestinal microflora studies in late-onset autism. Clin Infect Dis 2002 , 35:S6-SI 6.

30. Vanbelle M, Teller E, Focant M: Probiotics in animal nutrition: a review. Arch Tierernahr 1990, 40:543-567.

31. Ricke SC, Pillai SD: Conventional and molecular methods for understanding probiotic bacteria functionality in gastrointestinal tracts. Crit Rev Microbiol 1999, 25:19-38.

32. Drasar BS, Barrow PA: Intestinal Microbiology Wokingham, UK, Van Nostrand Reinhold; 1985.

33. Grizard D, Barthomeuf C: Non-digestible oligosaccharides used as prebiotic agents: mode of production and beneficial effects on animal and human health. Reprod Nutr Dev 1999, 39:563-588.

34. Kanauchi O, Matsumoto $Y$, Matsumura M, Fukuoka M, Bamba T: The beneficial effects of microflora, especially obligate anaerobes, and their products on the colonic environment in inflammatory bowel disease. Curr Pharm Des 2005, I I : 1047-1053.

35. Attwood G, Li D, Pacheco D, Tavendale M: Production of indolic compounds by rumen bacteria isolated from grazing ruminants. J Appl Microbiol 2006, I00:126I-127I.

36. Songer JG: The emergence of Clostridium difficile as a pathogen of food animals. Anim Health Res Rev 2004, 5:321-326.

37. Songer JG: Clostridial diseases of small ruminants. Vet Res 1998, 29:219-232.

38. Reilly K, Attwood GT: Detection of Clostridium proteoclasticum and closely related strains in the rumen by competitive PCR. Appl Environ Microbiol 1998, 64:907-913.

39. Widyastuti Y, Lee SK, Suzuki K, Mitsuoka T: Isolation and characterization of rice-straw degrading clostridia from cattle rumen. J Vet Med Sci 1992, 54: I85-188.

40. Kopecny J, Hodrova B, Stewart CS: The effect of rumen chitinolytic bacteria on cellulolytic anaerobic fungi. Lett Appl Microbiol 1996, 23:199-202.

4I. van der Wielen PW, Lipman LJ, van KF, Biesterveld S: Competitive exclusion of Salmonella enterica serovar Enteritidis by Lactobacillus crispatus and Clostridium lactatifermentans in a sequencing fed-batch culture. Appl Environ Microbiol 2002, 68:555-559.

42. Leser TD, Amenuvor JZ, Jensen TK, Lindecrona RH, Boye M, Moller $\mathrm{K}$ : Culture-independent analysis of gut bacteria: the pig gastrointestinal tract microbiota revisited. Appl Environ Microbiol 2002, 68:673-690.

43. Ozutsumi Y, Hayashi H, Sakamoto M, Itabashi H, Benno Y: Cultureindependent analysis of fecal microbiota in cattle. Biosci Biotechnol Biochem 2005, 69:1793-1797.

44. Wexler HM: Bacteroides: the good, the bad, and the nittygritty. Clin Microbiol Rev 2007, 20:593-62I

45. Shoemaker NB, Anderson KL, Smithson SL, Wang GR, Salyers AA: Conjugal transfer of a shuttle vector from the human colonic anaerobe Bacteroides uniformis to the ruminal anaerobe Prevotella (Bacteroides) ruminicola B(I)4. Appl Environ Microbiol |99|, 57:2| |4-2| 20.

46. Elad D, Friedgut O, Alpert N, Stram Y, Lahav D, Tiomkin D, Avramson M, Grinberg K, Bernstein M: Bovine necrotic vulvovaginitis associated with Porphyromonas levii. Emerg Infect Dis 2004, I 0:505-507.

47. Walter MR, Morck DW: In vitro expression of tumor necrosis factor-alpha, interleukin Ibeta, and interleukin 8 mRNA by 
bovine macrophages following exposure to Porphyromonas levii. Can J Vet Res 2002, 66:93-98.

48. Wise MG, Siragusa GR: Quantitative analysis of the intestinal bacterial community in one- to three-week-old commercially reared broiler chickens fed conventional or antibioticfree vegetable-based diets. J Appl Microbiol 2007, 1 02: | | 38- I | 49.

49. Avgustin G, Wallace RJ, Flint HJ: Phenotypic diversity among ruminal isolates of Prevotella ruminicola: proposal of Prevotella brevis sp. nov., Prevotella bryantii sp. nov., and Prevotella albensis sp. nov. and redefinition of Prevotella ruminicola. Int J Syst Bacteriol 1997, 47:284-288.

50. Rautio M, Eerola E, Vaisanen-Tunkelrott ML, Molitoris D, Lawson P, Collins MD, Jousimies-Somer $\mathrm{H}$ : Reclassification of Bacteroides putredinis (Weinberg et al., 1937) in a new genus Alistipes gen. nov., as Alistipes putredinis comb. nov., and description of Alistipes finegoldii sp. nov., from human sources. Syst Appl Microbiol 2003, 26:182-188.

5I. Scupham J, Patton TG, Bent E, Bayles DO: Comparison of the Cecal Microbiota of Domestic and Wild Turkeys. Microb Ecol 2008.

52. Hernandez JD, Scott PT, Shephard RW, Al Jassim RA: The characterization of lactic acid producing bacteria from the rumen of dairy cattle grazing on improved pasture supplemented with wheat and barley grain. J Appl Microbiol 2008.

53. Uyeno $Y$, Sekiguchi $Y$, Tajima K, Takenaka A, Kurihara M, Kamagata $Y$ : Evaluation of group-specific, I6S rRNA-targeted scissor probes for quantitative detection of predominant bacterial populations in dairy cattle rumen. J Appl Microbiol 2007 103:1995-2005

54. Min BR, Pinchak WE, Anderson RC, Hume ME: In vitro bacterial growth and in vivo ruminal microbiota populations associated with bloat in steers grazing wheat forage. J Anim Sci 2006 84:2873-2882

55. Cornick NA, Jensen NS, Stahl DA, Hartman PA, Allison MJ: Lachnospira pectinoschiza sp. nov., an anaerobic pectinophile from the pig intestine. Int J Syst Bacteriol 1994, 44:87-93.

56. Harmsen HJ, Raangs GC, He T, Degener JE, Welling GW: Extensive set of I6S rRNA-based probes for detection of bacteria in human feces. Appl Environ Microbiol 2002, 68:2982-2990.

57. Jay MT, Cooley M, Carychao D, Wiscomb GW, Sweitzer RA, Craw ford-Miksza L, Farrar JA, Lau DK, O'Connell J, Millington A, Asmundson RV, Atwill ER, Mandrell RE: Escherichia coli O157:H7 in feral swine near spinach fields and cattle, central California coast. Emerg Infect Dis 2007, 13:1908-1911.

58. Shelton DR, Karns JS, Higgins JA, Van Kessel JA, Perdue ML, Belt KT, Russell-Anelli J, Debroy C: Impact of microbial diversity on rapid detection of enterohemorrhagic Escherichia coli in surface waters. FEMS Microbiol Lett 2006, 261:95-10I.

59. Rodriguez A, Pangloli P, Richards HA, Mount JR, Draughon FA: Prevalence of Salmonella in diverse environmental farm samples. Food Prot 2006, 69:2576-2580

60. Vanselow BA, Hum S, Hornitzky MA, Eamens GJ, Quinn K: Salmonella Typhimurium persistence in a Hunter Valley dairy herd. Aust Vet J 2007, 85:446-450.

61. Callaway TR, Anderson RC, Edrington TS, Genovese KJ, Harvey RB, Poole TL, Nisbet DJ: Recent pre-harvest supplementation strategies to reduce carriage and shedding of zoonotic enteric bacterial pathogens in food animals. Anim Health Res Rev 2004, 5:35-47.

62. Callaway TR, Dunkley KD, Anderson RC, Edrington TS, Genovese KJ, Poole TL, Nisbet DJ: Probiotics, vaccines and other intervention strategies. In Raw Material Safety: Meat Edited by: Sofos JN. Cabridge, UK., Woohead Pub.; 2004:192-213.

63. Mead PS, Slutsker L, Dietz V, McCaig LF, Bresee JS, Shapiro C, Griffin PM, Tauxe RV: Food-related illness and death in the United States. Emerg Infect Dis 1999, 5:607-625.

64. Centers for Disease Control and Prevention: Multistate outbreak of Salmonella typhimurium infections associated with eating ground beef--United States, 2004. MMWR Morb Mortal Wkly Rep 2006, 55: $180-182$

65. Centers for Disease Control and Prevention: Outbreak of multidrug-resistant Salmonella newport--United States, JanuaryApril 2002. MMWR Morb Mortal Wkly Rep 2002, $51: 545-548$.

66. Dechet AM, Scallan E, Gensheimer K, Hoekstra R, Gunderman-King J, Lockett J, Wrigley D, Chege W, Sobel J: Outbreak of multidrugresistant Salmonellaenterica serotype Typhimurium Defini- tive Type 104 infection linked to commercial ground beef, northeastern United States, 2003-2004. Clin Infect Dis 2006 , 42:747-752.

67. Naylor SW, Low JC, Besser TE, Mahajan A, Gunn GJ, Pearce MC McKendrick IJ, Smith DG, Gally DL: Lymphoid follicle-dense mucosa at the terminal rectum is the principal site of colonization of enterohemorrhagic Escherichia coli O157:H7 in the bovine host. Infect Immun 2003, 71:1505-15I2.

68. Choi JH, Lee SH, Fukushi K, Yamamoto K: Comparison of sludge characteristics and PCR-DGGE based microbial diversity of nanofiltration and microfiltration membrane bioreactors. Chemosphere 2007, 67:1543-1550.

69. Binder A, Amtsberg G, Stock V, Bisping W: [Occurrence of Gramnegative anaerobic bacteria and clostridia in fecal flora of clinically healthy swine and weaned piglets with swine dysentery and nutritional diarrhea]. Zentralbl Veterinarmed B 1984 , 3I:40I-4I2.

70. Wittenbrink MM, Amtsberg G, Kamphues ]: [Intestinal and fecal flora of weaned piglets with nutritive diarrhea caused by forced feed intake]. Dtsch Tierarzt/ Wochenschr 1984, 91:387-39|.

71. Bryant MP: Normal flora--rumen bacteria. Am J Clin Nutr 1970, 23:1440-1450.

72. Attebery HR, Sutter VL, Finegold SM: Effect of a partially chemically defined diet on normal human fecal flora. Am J Clin Nutr 1972, 25:139|-1398.

73. Biesheuvel MH, Bijker PG, Urlings HA: Some aspects of the gastrointestinal microflora of veal calves fed different rations: a pilot study. Vet $Q$ 1991, I3:97-104.

74. Ellinger DK, Muller LD, Glantz PJ: Influence of feeding fermented colostrum and Lactobacillus acidophilus on fecal flora of dairy calves. J Dairy Sci 1980, 63:478-482.

75. Hara $\mathrm{H}$, Orita $\mathrm{N}$, Hatano $\mathrm{S}$, Ichikawa $\mathrm{H}$, Hara $\mathrm{Y}$, Matsumoto $\mathrm{N}$, Kimura $\mathrm{Y}$, Terada A, Mitsuoka T: Effect of tea polyphenols on fecal flora and fecal metabolic products of pigs. J Vet Med Sci 1995, 57:45-49.

76. Huang $X$, Madan A: CAP3: A DNA sequence assembly program. Genome Res 1999, 9:868-877.

77. Altschul SF, Gish W, Miller W, Myers EW, Lipman DJ: Basic local alignment search tool. J Mol Biol 1990, 21 5:403-4I0.

78. Maidak BL, Cole JR, Lilburn TG, Parker CT Jr., Saxman PR, Farris RJ, Garrity GM, Olsen G], Schmidt TM, Tiedje JM: The RDP-II (Ribosomal Database Project). Nucleic Acids Res 200I, 29:173-174.

Publish with Bio Med Central and every scientist can read your work free of charge

"BioMed Central will be the most significant development for disseminating the results of biomedical research in our lifetime. "

Sir Paul Nurse, Cancer Research UK

Your research papers will be:

- available free of charge to the entire biomedical community

- peer reviewed and published immediately upon acceptance

- cited in PubMed and archived on PubMed Central

- yours - you keep the copyright
BioMedcentral 